\title{
Leprosy and Kaposi sarcoma presenting as an immune reconstitution inflammatory syndrome in a patient with AIDS
}

\author{
Sandra Medeiros, MD, ${ }^{\mathrm{a}}$ Ricardo Coelho, MD, ${ }^{\mathrm{a}}$ Cândida Fernandes, MD, ${ }^{\mathrm{a}}$ Maria Carmo Catarino, MD, ${ }^{\mathrm{b}}$ \\ Ana Afonso, MD, ${ }^{\mathrm{c}}$ Raquel Vieira, MD, ${ }^{\mathrm{a}}$ Ana Rodrigues, MD, ${ }^{\mathrm{a}}$ and Jorge Cardoso, $\mathrm{MD}^{\mathrm{a}}$ \\ Lisbon, Portugal
}

\begin{abstract}
The simultaneous presence of infectious organisms within cutaneous lesions of Kaposi sarcoma in persons with AIDS has been demonstrated. We describe a patient with concurrent leprosy and Kaposi sarcoma presenting as an immune reconstitution inflammatory syndrome in the setting of AIDS. ( $\mathrm{J}$ Am Acad Dermatol 2009;61:516-8.)
\end{abstract}

\section{CASE REPORT}

We report a 46-year-old woman, born in Angola who resided in Portugal since 1999. She had been monitored by the infectious disease department of our hospital since the diagnosis of HIV-1 infection in 2005. At that time she had a blood CD $4^{+}$lymphocyte count of 91 cells $/ \mathrm{mL}$ and a plasma virus load of 37,369 HIV RNA copies/mL. Highly active antiretroviral therapy (HAART) (zidovudine, lamivudine, and efavirenz) was started. After 4 months, the patient reported the appearance of skin lesions that first developed on her face and subsequently spread caudally. She also reported a burning sensation in hands and feet, nasal obstruction, and mucosal rhinorrhea.

Cutaneous examination revealed a dimorphic eruption. Her face and extremities showed localized areas of multiple $0.5-$ to $1-\mathrm{cm}$ skin-colored firm papules (60-80 in total). Intermixed with these papules there were nodules and plaques with a bright and smooth surface, slightly darker than normalappearing skin, each approximately 1 to $3 \mathrm{~cm}$ in diameter (10-15 in total) (Fig 1, $A$ ). The patient also had supraciliary madarosis, edema localized to both hands and feet, and ichthyosiform scaling of both legs. Many confluent, violaceous-brownish macules with a superficial white fine scale were observed on the soles of the feet (Fig 1,B). There were no mucosal

\footnotetext{
From the Dermatology Department, ${ }^{\text {a }}$ Infectious Disease Department, ${ }^{\mathrm{b}}$ and Pathology Department, ${ }^{\mathrm{c}}$ Curry Cabral Hospital.

Funding sources: None.

Conflicts of interest: None declared.

Reprint requests: Sandra Medeiros, MD, Curry Cabral Hospital, Rua da Beneficiência $n^{\circ} 8,1069-166$ Lisbon, Portugal. E-mail: sandradmedeiros@clix.pt.

Published online July 9, 2009.

0190-9622/\$36.00

(c) 2008 by the American Academy of Dermatology, Inc.

doi:10.1016/j.jaad.2008.11.885
}

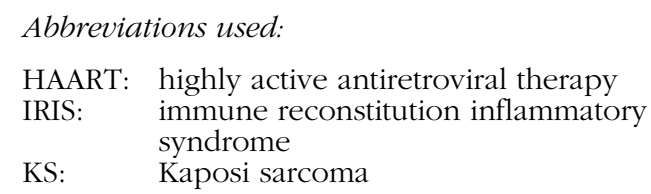

lesions or palpable lymphadenopathy. Neurologic examination revealed loss of sensation to light touch in some skin lesions, anesthesia of both legs from the feet to the knees, and a thickened painful left ulnar nerve. As a result, the clinical diagnosis of leprosy and Kaposi sarcoma (KS) was suspected.

Skin and mucous bacteriological indices were positive $(4+, 4+)$ according to Ridley-Jopling classification. Histopathology of a skin biopsy specimen from a plaque on the back of the right hand confirmed the diagnosis: a dense and diffuse inflammatory infiltrate of lymphocytes, histiocytes (some with cytoplasmic vacuolization), and plasmocytes extending from the papillary deeper dermis. With FiteFaraco stain, numerous intracellular and extracellular bacilli were visible. The nerves were also affected by this inflammatory process and by the presence of multiple bacilli. In addition, we observed intermingled spindle-shaped cells forming slitlike spaces, associated with extravascular erythrocytes. Human herpesvirus-8-associated antigens were detected in situ by immunohistochemistry (Fig 2).

Six months after the onset of HAART the patient's plasma virus load was less than 50 HIV-1 RNA copies/mL and her $\mathrm{CD}^{+}$lymphocyte count had increased to 283 cells $/ \mathrm{mL}$. Accordingly, the diagnosis of borderline lepromatous leprosy with reversal (type1) reaction, associated with $\mathrm{KS}$ and presenting as an immune reconstitution inflammatory syndrome (IRIS), was confirmed. The World Health Organizationrecommended multidrug therapy for patients with 

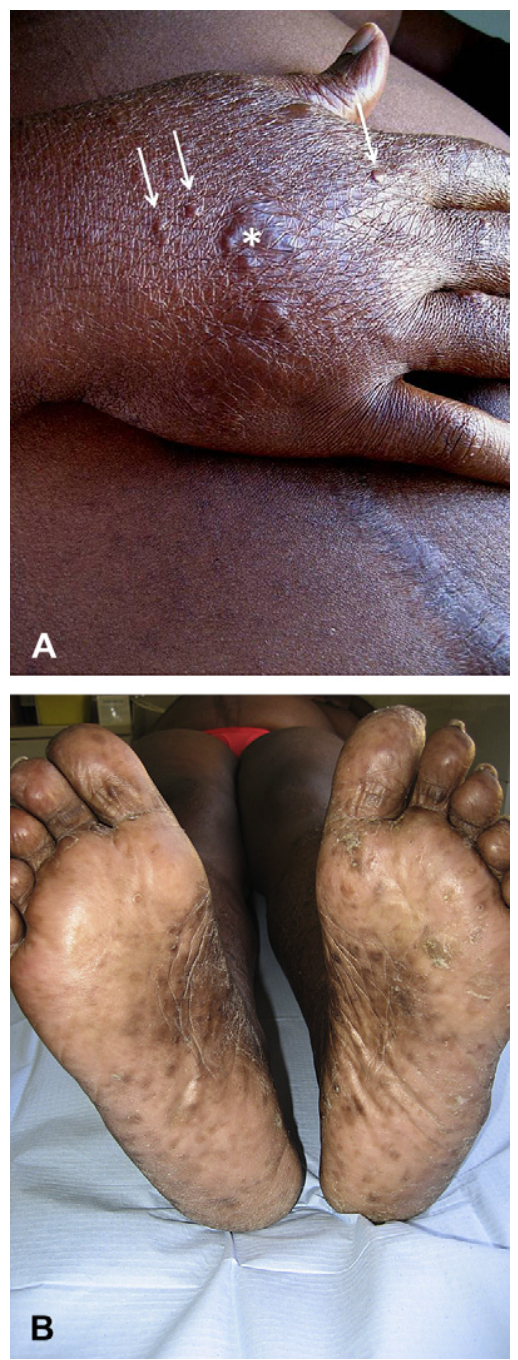

Fig 1. A, Cutaneous lesions of borderline lepromatous leprosy (arrows) intermingled with Kaposi sarcoma lesions (asterisk). B, Confluent violaceous macules on soles of feet compatible with Kaposi sarcoma.

multibacillary leprosy was started, and the erythema and edema caused by the reversal reaction initially decreased in response to additional treatment with prednisolone $(40 \mathrm{mg} / \mathrm{d})$, with slow tapering over 4 months. KS lesions progressively regressed.

\section{DISCUSSION}

The coexistence of multiple entities within a single lesion is not without precedent in patients with HIV-1., In fact, leprosy and HIV infection coexist, mainly in Africa, Brazil, and India, and reactional states linked to the introduction of HAART have been recently described in 19 patients with Mycobacterium leprae and HIV coinfection (16 male). ${ }^{3-15}$ Since its first report in 2003, it has become clear that the introduction of HAART changed the natural history of leprosy in HIV-infected patients. ${ }^{3,15}$ In 19 cases (including the patient we describe) the clinical manifestations of IRIS were leprosy type- 1 reactions, some unusually severe and associated with vasculitis and ulcerous progression. $^{8}$

Although it seems that leprosy manifesting as IRIS is similar to leprosy type-1 reactions, in which there is an overaction of T-helper-1 lymphocyte responses to $M$ leprae antigens, it is interesting to notice that the pathomechanisms of both are different. ${ }^{14,15}$ In the former, the primary event is restoration of immunity by HAART, which then recognizes and mounts an immune response against the bacilli. In contrast, in classic type- 1 leprosy reactions, there is initial lysis of bacilli by multidrug therapy that then restores the immune system and this reconstituted immune response leads to a type-1 reaction. ${ }^{11,16}$ Furthermore, all reported cases belong to the tuberculoid spectrum of leprosy, implying that there is a good immune host response. This is not true for two patients (including the current one) with borderline lepromatous multibacillary disease; these patients were probably anergic against mycobacteria and as HAART increased cellular immune response, it triggered reactional type-1 leprosy, instead of type-2 reactions. ${ }^{13}$

These cases may, therefore, provide indirect evidence that, at least in some patients, the clinical presentation of leprosy is suppressed by HIV-associated advanced immunodeficiency until HAART provides the immunologic "trigger" that leads to disease presentation, in all cases within 6 months after the introduction of HAART. 8,15

An association between KS and HIV infection is also well established. ${ }^{2}$ Nevertheless, the association among leprosy, KS, and AIDS has only been reported in 3 patients. ${ }^{2,17}$

The temporal association between the development of skin lesions and changes in blood $\mathrm{CD}^{+}$ lymphocyte count and plasma HIV-1 load observed during HAART strongly suggests that the presentation of these two conditions resulted from IRIS. Finally, it is also important to state that if the presentation of these 2 diseases as an IRIS can be detected even in a low leprosy-endemic country such as Portugal, an increase in similar cases can be anticipated in areas where HIV and leprosy occur in higher frequencies, especially as access to HAART becomes more widely available.

\section{REFERENCES}

1. Sofman MS, Heilman ER. Simultaneous occurrence of Kaposi's sarcoma and Cryptococcus within a cutaneous lesion in a patient with acquired immunodeficiency syndrome. Arch Dermatol 1990;126:683-4. 

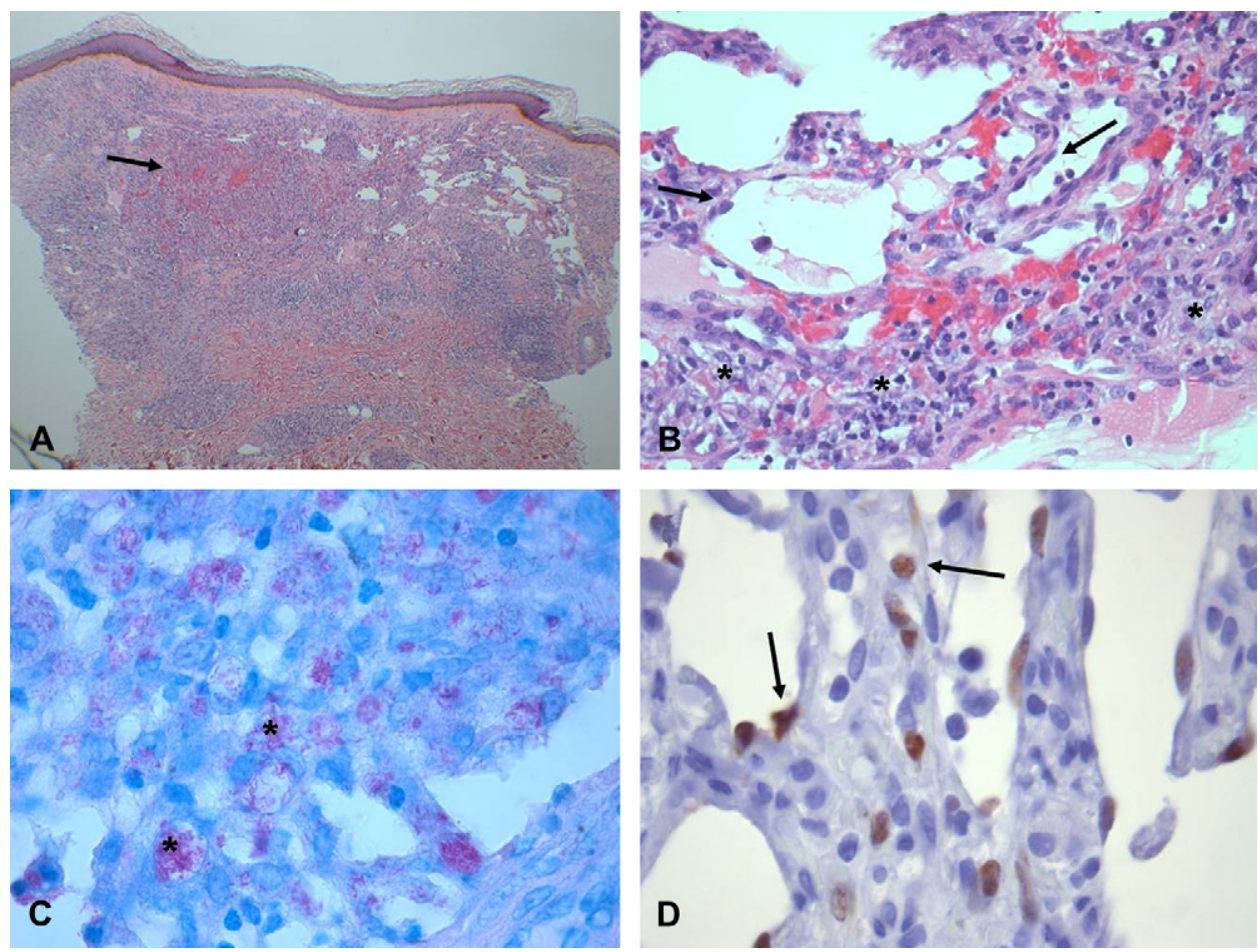

Fig 2. A, Among dense inflammatory infiltrate we observed typical histologic findings of Kaposi sarcoma: proliferation of spindle cells, bizarre vascular spaces, and anastomosing slitlike spaces with extravasated red blood cells (arrow). B, Note vascular channels lined by slightly atypical endothelial cells (arrows) and intermingled vacuolized histiocytes (Virchow cells [asterisk]). C, Fite-Faraco stain shows numerous acid-fast bacilli (asterisk). D, Positive nuclear immunostaining for antihuman herpesvirus-8 (latent nuclear antigen 1) in neoplastic endothelial cells (arrows). (A and $\mathbf{B}$, Hematoxylin-eosin stain; original magnifications: $\mathbf{A}, \times 50$; $\mathbf{B}, \times 400$. $)(\mathbf{C}$ and $\mathbf{D}$, Original magnifications: $\times 1000$. $)$

2. Bwire R, Kawuma HJ. Leprosy, Kaposi's sarcoma and the acquired immunodeficiency syndrome in two African patients. Trans R Soc Trop Med Hyg 1993;87:559.

3. Lawn SD, Wood C, Lockwood DN. Borderline tuberculoid leprosy: an immune reconstitution phenomenon in a human immunodeficiency virus-infected person. Clin Infect Dis 2003; 36:e5-6.

4. Couppié $P$, Abel $S$, Voinchet $H$, Roussel $M$, Hélénon $R$, Huerre $M$, et al. Immune reconstitution inflammatory syndrome associated with HIV and leprosy. Arch Dermatol 2004;140: 997-1000.

5. Pignataro P, Rocha Ada S, Nery JA, Miranda A, Sales AM, Ferrreira $\mathrm{H}$, et al. Leprosy and AIDS: two cases of increasing inflammatory reactions at the start of highly active antiretroviral therapy. Eur J Clin Microbiol Infect Dis 2004;23:408-11.

6. Visco-Comandini U, Longo B, Cuzzi T, Paglia MG, Antonucci G. Tuberculoid leprosy in a patient with AIDS: a manifestation of immune restoration syndrome. Scand J Infect Dis 2004;36: 881-3.

7. Pereira GA, Stefani MM, Araújo Filho JA, Souza LC, Stefani GP, Martelli CM. Human immunodeficiency virus type 1 (HIV-1) and Mycobacterium leprae co-infection: HIV-1 subtypes and clinical, immunologic, and histopathologic profiles in a Brazilian cohort. Am J Trop Med Hyg 2004;71:679-84.

8. Narang T, Dogra S, Kaur I. Borderline tuberculoid leprosy with type 1 reaction in an HIV patient-a phenomenon of immune reconstitution. Int J Lepr Other Mycobact Dis 2005; 73:203-5.
9. Trindade MA, Manini MI, Masetti JH, Leite MA, Takahashi MD, Naafs B. Leprosy and HIV co-infection in five patients. Lepr Rev 2005;76:162-6.

10. Singal A, Mehta S, Pandhi D. Immune reconstitution inflammatory syndrome in an HIV seropositive leprosy patient. Lepr Rev 2006;77:76-8.

11. Kharkar V, Bhor UH, Mahajan S, Khopkar U. Type I lepra reaction presenting as immune reconstitution inflammatory syndrome. Indian J Dermatol Venereol Leprol 2007;73:253-6.

12. Talhari C, Machado PR, Ferreira LC, Talhari S. Shifting of the clinical spectrum of leprosy in an HIV-positive patient: a manifestation of immune reconstitution inflammatory syndrome? Lepr Rev 2007;78:151-4.

13. Batista MD, Porro AM, Maeda SM, Gomes EE, Yoshioka MC, Enokihara MM, et al. Leprosy reversal reaction as immune reconstitution inflammatory syndrome in patients with AIDS. Clin Infect Dis 2008;46:e56-60.

14. Deps PD, Gripp CG, Madureira BP, Lucas EA. Immune reconstitution syndrome associated with leprosy: two cases. Int J STD AIDS 2008;19:135-6.

15. Deps PD, Lockwood DN. Leprosy occurring as immune reconstitution syndrome. Trans R Soc Trop Med Hyg 2008;102:966-8.

16. Ustianowski AP, Lawn SD, Lockwood DN. Interactions between HIV infection and leprosy: a paradox. Lancet Infect Dis 2006;6:350-60.

17. Lamfers EJ, Bastiaans AH, Mravunac M, Rampen FH. Leprosy in the acquired immunodeficiency syndrome. Ann Intern Med 1987;107:111-2. 